\title{
Pengaruh Kompetensi Pedagogik Guru terhadap Prestasi Belajar Siswa Madrasah Aliyah (MA) An-Nur Kota Cirebon (Studi pada Pembelajaran Aqidah Akhlak)
}

\author{
Endang Afriyani,Suklani, Wawan A. Ridwan \\ Fakultas Ilmu Tarbiyah dan Keguruan \\ Institut Agama Islam Negeri Syekh Nurjati Cirebon
}

\begin{abstract}
Abstrak
Berdasarkan studi pendahuluan, diketahui bahwasanya telah ditemukan masalah mengenai kemampuan guru dalam mengelola kegiatan belajar mengajar di Madrasah Aliyah (MA) An-Nur Kota Cirebon, dimana bapak Abdul Hamid Yahya selaku guru Aqidah Akhlak di Madrasah Aliyah (MA) An-Nur Kota Cirebon dalam menyampaikan pembelajaran di kelas masih dikatakan kurang baik dalam mengelola kelas, hal ini ditunjukan bahwasanya pada saat pembelajaran guru hanya menerangkan materi sambil duduk di meja, sehingga pembelajaran cenderung monoton dan tidak menyenangkan, selain itu juga ada siswa yang tidur di dalam kelas, dan siswapun sulit berkonsentrasi dalam belajar, hal tersebut membuat siswa kurang antusias untuk mengikuti pembelajaran Aqidah Akhlak.

Tujuan penelitian ini yaitu untuk: (1) mengetahui kompetensi pedagogik guru di Madrasah Aliyah (MA) An-Nur Kota Cirebon, (2) mengetahui seberapa besar prestasi belajar siswa pada pembelajaran Akidah Akhlak, (3) mengetahui seberapa besar pengaruh kompetensi pedagogik guru terhadap prestasi belajar siswa Madrasah Aliyah (MA) An-Nur Kota Cirebon (studi pada pembelajaran Aqidah Akhlak).

Metode pengumpulan data pada penelitian ini menggunakan observasi, angket dan dokumentasi tentang pengaruh kompetensi pedagogik guru. Teknik analisis data yang digunakan dalam penelitian ini ialah teknik analisis data kuantitatif. Sedangkan untuk menganalisa data yang diperoleh peneliti menggunakan skala prosentase, mean, median modus, dan rumus product moment.

Berdasarkan hasil penelitian dapat disimpulkan bahwa pengaruh kompetensi pedagogik guru terhadap prestasi belajar siswa Madrasah Aliyah (MA) An-Nur Kota Cirebon (studi pada pembelajaran Aqidah Akhlak) dimana dilihat dari " $r$ " product moment" dihasilkan nilai $r$ sebesar 0,729 kemudian $r$ hitung di atas dikonsultasikan ke $r$ tabel pada sampel sebesar 34 diperoleh $r$ tabel 0,349. Dengan begitu dapat dikatakan bahwa $r$ hitung berada di atas $r$ tabel, maka uji hipotesis menjawab $\mathrm{H}_{0}$ ditolak dan $\mathrm{H}_{a}$ diterima.
\end{abstract}

Kata Kunci: Kompetensi Pedagogik Guru, Prestasi Belajar

\section{A. Pendahuluan}


Kompetensi merupakan komponen utama dari standar profesi disamping kode etik sebagai regulasi perilaku profesi yang ditetapkan dalam prosedur dan sistem pengawasan tertentu.Kompetensi diartikan dan dimaknai sebagai perangkat perilaku efektif yang terkait dengan eksplorasi dan investigasi, menganalisis dan memikirkan, serta memberikan perhatian, dan mempersepsi yang mengarahkan seseorang menemukan cara-cara untuk mencapai tujuan tertentu secara efektif dan efisien. Kompetensi bukanlah suatu titik akhir dari suatu upaya melainkan suatu proses yang berkembang dan belajar sepanjang hayat. ${ }^{1}$

Kompetensi terkait erat dengan standar.Seseorang disebut kompeten dalam bidangnya jika pengetahuan, keterampilan, dan sikapnya, serta hasil kerjanya sesuai dengan standar (ukuran) yang ditetapkan dan diakui oleh lembaganya/pemerintah. Wolf $(1995,40)$ menegaskan bahwa "Competence is the apability to perform: in the case, to perform at the standards expected of employees,"2

Dalam Undang-Undang tentang Guru dan Dosen pada pasal 1 ayat 10 dinyatakan bahwa kompetensi adalah seperangkat pengetahuan, keterampilan , dan perilaku yang harus dimiliki, dihayati, dan dikuasai oleh guru atau dosen dalam melaksanakan tugas keprofesionalan. ${ }^{3}$

Kompetensi guru merupakan perpaduan antara kemampuan personal, keilmuan, teknologi, sosial, dan spiritual yang secara kaffah membentuk kompetensi standar profesi guru, yang mencakup penguasaan materi, pemahaman, terhadap peserta didik, pembelajaran yang mendidik, pengembangan pribadi dan profesionalisme. ${ }^{4}$

Dalam penjelasan Pasal 10 Undang-Undang RI No.14 Tahun 2005 Tentang Guru dan Dosen diuraikan tentang keempat kompetensi tersebut, yaitu: Kompetensi pedagogik adalah kemampuan mengelola pembelajaran peserta didik. Yang dimaksud dengan kompetensi kepribadian adalah kemampuan kepribadian yang mantap, berakhlak mulia, arif, dan berwibawa serta menjadi teladan peserta didik. Yang dimaksud dengan kompetensi profesional adalah kemampuan penguasaan materi pelajaran secara luas dan mendalam. Yang dimaksud dengan kompetensi sosial adalah kemampuan guru untuk berkomunikasi dan berinteraksi secara efektif dan efisien dengan peserta didik, sesama guru, orang tua/wali peserta didik, dan masyarakat sekitar. ${ }^{5}$

Keempat kompetensi tersebut bukan hanya wajib dimiliki, dihayati, dan dikuasai oleh guru, tetapi juga wajib ditingkatkan dan dikembangkan oleh guru secara terus menerus dan dinamis. Hal ini sebagaimana diamanatkan 2011), 26

${ }^{1}$ E. Mulyasa, Standar Kompetensi dan Sertifikasi Guru (Bandung: PT Remaja Rosdakarya,

${ }^{2}$ Jejen Musfah, Peningkatan Kompetensi Guru (Melalui Pelatihan dan Sumber Belajar Teori dan Praktek),(Jakarta: Kencana Prenada Media Group, 2012), 28.

${ }^{3}$ Undang-Undang RI tentang Guru dan Dosen No 14 Tahun 2005 (Jakarta: Sinar Grafika, 2010), 4.

${ }^{4}$ E. Mulyasa,Standar Kompetensi........., 26.

${ }^{5}$ Undang-Undang RI tentang Guru dan Dosen No 14 Tahun 2005, , $56-57$. 
dalam UU RI No. 14 Tahun 2005 tentang Guru dan Dosen, pasal 20 huruf (b) bahwa dalam melakasanakan tugas keprofesionalan, guru wajib meningkatkan dan mengembangkan kualifikasi akademik dan kompetensi secara berkelanjutan sejalan dengan perkembangan ilmu pengetahuan, teknologi, dan seni. ${ }^{6}$

Kompetensi pedagogik merupakan kemampuan yang berkaitan dengan pemahaman siswa dan pengelolaan pembelajaran yang mendidik dan dialogis. ${ }^{7}$ Adapun indikator kompetensi pedagogik yaitu antara lain: a) menguasai karakteristik peserta didik, b) menguasai teori belajar dan prinsipprinsip pembelajaran yang mendidik, c) pengembangan kurikulum, d) kegiatan pembelajaran yang mendidik, e) pengembangan potensi peserta didik, f) komunikasi dengan peserta didik, dan g) penilaian dan evaluasi. ${ }^{8}$

Kemampuan guru dalam mengelola pembelajaran atau biasa disebut kompetensi pedagogik dijelaskan dalam Al-Qur'an Surah An-Nahl ayat 125 sebagai berikut:

"Serulah (manusia) kepada jalan Tuhan-Mu dengan hikmah dan pelajaran yang baik serta bantahlah mereka dengan cara yang baik. Sesungguhnya Tuhanmu Dialah yang lebih mengetahui siapa yang tersesat dari jalan-Nya dan Yang lebih mengetahui orang-orang yang mendapat petunjuk" ${ }^{\text {"9 }}(\mathrm{QS}$. AnNahl: 125)

Dalam ayat di atas disebutkan bahwa Nabi Muhammad SAW mengajak semua orang agar mengikuti ajaran-ajaran Allah SWT. Ayat ini menyatakan: Wahai Nabi Muhammad, serulah, yakni lanjutkan usahamu untuk menyeru semua yang engkau sanggup seru kepada jalan yang ditunjukkan Tuhanmu, yakni ajaran Islam dengan hikmah dan pengajaran yang baik dan bantahlah mereka, yakni siapa pun yang menolak atau meragukan ajaran Islam dengan cara yang terbaik dipahami oleh ulama menjelaskan tentang tiga macam metode dakwah yang harus disesuaikan dengan sasaran dakwah. Terhadap cendekiawan yang memiliki pengetahuan tinggi diperintahkan dengan hikmah, yakni berdialog dengan kata-kata bijak sesuai dengan tingkat kepribadian mereka.Terhadap kaum awam, diperintahkan untuk menerapkan mau'izah, yakni memberikan nasihat dan perumpamaan yang menyentuh jiwa sesuai dengan taraf pengetahuan mereka yang sederhana. Sedang terhadap Ahl al-Kitab dan penganut agama-agama lain yang diperintahkan adalah jidal/perdebatan dengan cara yang terbaik yaitu dengan logika dan retorika yang halus, lepas dari kekerasan dan umpatan. ${ }^{10}$

Penjelasan di atas bahwasanya selaras dengan kompetensi pedagogik yang harus dimiliki oleh seoarang guru dalam mengelola pembelajaran.

${ }^{6}$ Undang-Undang RI tentang Guru dan Dosen No 14 Tahun 2005, ........., 14

${ }^{7}$ Supratiningrum Jamil, Guru Profesional Pedoman Kinerja, Kualifikasi, dan Kompetensi Guru (Jogjakarta: Ar Ruzz Media, 2014), 101.

${ }^{8}$ Nur Irwantoro dan Yusuf Suryana, Kompetensi Pedagogik.(Surabaya: Genta Group Production, 2016), 4.

${ }^{9}$ Kementrian Agama, Al-Qur'an dan Terjemahan(Jakarta: PT Sinergi Pustaka Indonesia, 2009), 281.

${ }^{10}$ M. Quraish Shihab, (2002), 383-384. 
Dalam setiap dakwahnya Rasulullah selalu menggunakan metode yang berbeda-beda karena agar para pendengarnya dapat mengerti apa yang telah disampaikan oleh beliau, begitu juga dengan guru yang harus bisa mengelola pembelajaran di dalam kelas agar tidak terkesan monoton.

Secara pedagogis, kompetensi guru-guru dalam mengelola pembelajaran perlu mendapat perhatian, karena pendidikan di Indonesia dinyatakan kurang berhasil, dinilai kering dari aspek pedagogis, dan sekolah nampak lebih mekanis sehingga peserta didik cenderung kerdil karena tidak mempunyai dunianya sendiri. ${ }^{11}$

Slameto menyatakan bahwa "dalam proses belajar mengajar, guru mempunyai tugas untuk mendorong, membimbing dan memberi fasilitas belajar bagi siswa untuk mencapai tujuan". Pernyataan tersebut menjelaskan bahwa guru merupakan kunci pokok terciptanya kegiatan belajar mengajar yang efektif, efisien dan bermakna sehingga dapat mencapai keberhasilan belajar yang diharapkan.Keberhasilan belajar sendiri dapat dilihat dari perolehan prestasi belajar siswa yang optimal. $^{12}$

Pada umumnya, keberhasilan prestasi belajar siswa dipengaruhi oleh berbagai faktor. Menurut Djaali "faktor yang mempengaruhi belajar siswa ada dua macam yaitu faktor internal dan eksternal". Faktor internal berasal dari dalam diri siswa sendiri, meliputi intelegensi, minat, motivasi, kesehatan dan cara belajar, sedangkan faktor eksternal berasal dari luar diri siswa meliputi lingkungan keluarga, sekolah dan masyarakat. Selain faktor-faktor tersebut juga terdapat faktor lain yang mempunyai peranan tidak kalah pentingnya dalam kegiatan belajar yaitu disiplin belajar. Disiplin belajar akan membuat siswa memiliki kecakapan mengenai cara belajar yang baik sehingga memperoleh prestasi belajar yang baik pula. ${ }^{13}$

Berdasarkan studi pendahuluan, diketahui bahwasanya telah ditemukan masalah mengenai kemampuan guru dalam mengelola kegiatan belajar mengajar di Madrasah Aliyah (MA) An-Nur Kota Cirebon, dimana bapak Abdul Hamid Yahya selaku guru Aqidah Akhlak di Madrasah Aliyah (MA) An-Nur Kota Cirebon dalam menyampaikan pembelajaran di kelas masih dikatakan kurang baik dalam mengelola kelas, hal ini ditunjukan bahwasanya pada saat pembelajaran guru hanya menerangkan materi sambil duduk di meja, sehingga pembelajaran cenderung monoton dan tidak menyenangkan, selain itu juga ada siswa yang tidur di dalam kelas, dan siswapun sulit berkonsentrasi dalam belajar, hal tersebut membuat siswa kurang antusias untuk mengikuti pembelajaran Aqidah Akhlak.

Berdasarkan hasil observasi pada pembelajaran Aqidah Akhlak, ketika guru menyampaikan materi pembelajaran Aqidah Akhlak, peserta didik hanya mendengarkan apa yang disampaikan oleh guru tanpa memahami materi tersebut, sehingga pada proses tanya jawab peserta didik tidak bisa menjawab pertanyaan yang diberikan oleh guru. Ketika diskusi peserta didik hanya

${ }^{1}$ E. Mulyasa, Standar Kompetensi.............., 76.

${ }^{12}$ Slameto, Belajar dan Faktor-faktor yang Mempengaruhinya(Jakarta: PT Renika Cipta, 2010),97.

${ }^{13}$ Djaali, (2014), 99. 
mengandalkan peserta didik yang pintar saja, sehingga peserta didik yang lain hanya mendengarkan apa yang di sampaikan oleh peserta didik tersebut.

Berdasarkan realita yang ada di Madrasah, banyak faktor yang memengaruhi prestasi belajar siswa anatara lain motivasi belajar, perhatian orang tua, fasilitas belajar, disiplin belajar, dan lain-lain. Hal ini disebabkan karena masing-masing siswa memiliki cara belajar yang berbeda-beda bisa dilihat dari motivasi belajar, perhatian orang tua, dan yang terpenting yaitu kesadaran diri untuk belajar

Berdasarkan pemaparan di atas, makapeneliti tertarik untuk melakukan penelitian tentang pengaruh kompetensi pedagogik guru terhadap prestasi belajar siswa Madrasah Aliyah (MA) An-Nur Kota Cirebon (Studi pada Pembelajaran Aqidah Akhlak).

Berdasarkan latar belakang di atas, dapat penulis uraikan rumusan masalah sebagai berikut: 1) apakah kompetensi pedagogik guru di Madrasah Aliyah (MA) An-Nur Kota Cirebon dikategorikan baik?, 2) seberapa besar prestasi belajar siswa pada pembelajaran Aqidah Akhlak?, 3) seberapa besar pengaruh kompetensi pedagogik guru terhadap prestasi belajar siswa pada pembelajaran Aqidah Akhlak?

Setiap kegiatan yang dilakukan harus memiliki tujuan yang jelas. Begitu pula dengan penelitian ini, yang bertolak pada rumusan masalah. Adapun tujuan dari penelitian ini adalah: 1) untuk mengetahui kompetensi pedagogik guru di Madrasah Aliyah (MA) An-Nur Kota Cirebon, 2) untuk mengetahui seberapa besar prestasi belajar siswa pada pembelajaran Aqidah Akhlak, 3) untuk mengetahui seberapa besar pengaruh kompetensi pedagogik guru terhadap prestasi belajar siswa pada pembelajaran Aqidah Akhlak.

\section{B. Pengaruh Kompetensi Pedagogik Guru terhadap Prestasi Belajar Siswa}

Menurut asal katanya, competency berarti kemampuan atau kecakapan. Selain memiliki arti kemampuan, kompetensi juga diartikan ... the state of being legally competent or qualified, yaitu keaadaan berwewenang atau memenuhi syarat menurut ketentuan hukum. ${ }^{14}$ Dalam Undang-Undang RI No. 14 Tahun 2005 tentang Guru dan Dosen pasal 1 ayat 10 disebutkan bahwa "kompetensi adalah seperangkat pengetahuan, keterampilan, dan perilaku yang harus dimiliki, dihayati, dan dikuasai oleh guru atau dosen dalam melaksanakan tugas keprofesionalannya". ${ }^{15}$

Menurut sumber lain, kompetensi adalah kumpulan pengetahuan, perilaku, dan keterampilan yang harus dimiliki guru untuk mencapai tujuan pembelajaran dan pendidikan. Kompetensi diperoleh melalui pendidikan, pelatihan, dan belajar mandiri dengan memanfaatkan sumber belajar. ${ }^{16}$

Adapun menurut Kusnandar kompetensi adalah seperangkat penguasaan kemampuan yang harus ada dalam diri guru agar dapat mewujudkan kinerjanya secara tepat dan efektif.Untuk itu guru perlu menguasai bahan pelajaran dan menguasai cara-cara mengajar, sebagai dasar

\footnotetext{
${ }^{14}$ Jamil, Supratiningrum, Guru Profesional .............., 97.

${ }^{15}$ Undang-Undang RI tentang Guru dan Dosen No 14 Tahun 2005, .........,4.

${ }^{16}$ Jejen Musfah, Peningkatan Kompetensi Guru........., 27.
} 
kompetensi. ${ }^{17}$ Bila guru tidak menguasai bahan pelajaran dan cara-cara mengajar maka guru gagal dalam melaksanakan tugasnya.Sedangkan menurut Triantokompetensi adalah kemampuan, kecakapan, yang dimiliki seseorang, dan keterampilan yang dimiliki seseorang berkenaan dengan tugas, jabatan, maupun profesinya. ${ }^{18}$

Pedagogik sebagai kata benda memiliki makna ilmu mendidik atau ilmu pengajaran. Dengan kata lain pedagogik tidak hanya berkutat pada ilmu mengajar dan seni mengajar, melainkan ada hubungannya dengan pembentukan generasi baru, yaitu pengaruh pendidikan sebagai sistem yang bermuara pada pengembangan individu peserta didik. ${ }^{19}$

Secara luas, kompetensi pedagogik guru adalah kemampuan mengelola pembelajaran peserta didik yang sekurang-kurangnya meliputi pemahaman wawasan atau landasan kependidikan, pemahaman terhadap peserta didik, perencanaan dan pelaksanaan pembelajaran, evaluasi hasil belajar, dan pengembangan peserta didik untuk mengaktualisasikan berbagai potensi yang dimilikinya. $^{20}$

Menurut Mulyasa kompetensi pedagogik adalah kemampuan mengelola pembelajaran peserta didik yang meliputi pemahaman terhadap peserta didik, perancangan dan pelaksanaan pembelajaran, evaluasi hasil belajar, dan pengembangan peserta didik untuk mengektualisasikan berbagai kompetensi yang dimilikinya sekurang-kurangnya meliputi hal-hal sebagai berikut ${ }^{21}$ :

a. Pemahaman wawasan dan landasan kependidikan

Guru sebagai tenaga pendidik yang sekaligus memiliki peran penting dalam upaya meningkatkan mutu pendidikan di negara ini, terlebih dahulu harus mengetahui dan memahami wawasan dan landasan kependidikan sebagai pengetahuan dasar. Pengetahuan awal tentang wawasan dan landasan kependidikan ini dapat diperoleh ketika guru mengambil pendidikan keguruan di perguruan tinggi.

b. Pemahaman terhadap peserta didik

Peserta didik adalah setiap orang yang menerima pengaruh dari seseorang atau sekelompok orang yang menjalankan kegiatan pendidikan. Tujuan guru mengenal siswa-siswanya adalah agar guru dapat membantu pertumbuhan dan perkembangannya secara efektif, menentukan materi yang akan diberikan, menggunakan prosedur mengajar yang serasi, mengadakan diagnosis atas kesulitan belajar yang dialami oleh siswa, dan kegiatan-kegiatan guru lainnya yang berkaitan dengan individu siswa.

\footnotetext{
${ }^{17}$ Kusnandar, Guru Profesional (Implementasi KTSP dan Sukses dalam Sertifikasi Guru),(Jakarta: Rajawali Perss, 2007), 55.

${ }^{18}$ Trianto, Pengantar penelitian Pendidikan bagi pengembangan profesi pendidikan dan tenaga kependidikan(Jakarta: Bumi Aksara, 2011), 53.

${ }^{19}$ Danim, (2010) hal. 69

${ }^{20}$ Uzer Muhammad Usman, Menjadi Guru Profesional (Bandung: Remaja Rosdakarya,
} 2006), 14.

${ }^{21}$ E. Mulyasa, Standar Kompetensi.........., 75. 
Dalam memahami siswa, guru perlu memberikan perhatian khusus pada perbedaan individual anak didik, antara lain:

1. Tingkat kecerdasan

Kecerdasan seseorang terdiri dari beberapa tingkat, yaitu: golongan terendah adalah mereka yang IQ-nya antara 0-50 dan di katakan idiot. Golongan kedua adalah mereka yang ber-IQ antara 5070 yang dikenal dengan golongan moron, yaitu keterbatasan mental.Golongan ketiga, yaitu mereka yang ber-IQ antara 70-90 disebut sebagai anak lambat atau bodoh.Golongan menengah merupakan bagian yang besar jumlahnya, yaitu golongan yang ber-IQ 90110.Mereka bisa belajar secara normal.Sedangkan yang ber IQ $140 \mathrm{ke}$ atas disebut genius, mereka mampu belajar jauh lebih cepat dari golongan lainnya. ${ }^{22}$

2. Kreativitas

Setiap orang memiliki perbedaan dalam kreativitas baik inter maupun intra individu. Orang yang mampu menciptakan sesuatu yang baru disebut dengan orang kreatif.Kreativitas erat hubungannya dengan intelegensi dan kepribadian.Seseorang yang kreatif pada umumnya memiliki intelegensi yang cukup tinggi dan suka hal-hal yang baru. ${ }^{23}$

3. Kondisi fisik

Kondisi fisik berkaitan dengan penglihatan, pendengaran, kemampuan berbicara, pincang (kaki), dan lumpuh karena kerusakan otak. Guru harus memberikan layanan yang berbeda terhadap peserta didik yang memiliki kelainan seperti diatas dalam rangka membantu perkembangan pribadi mereka. Misalnya dalam hal jenis media yang digunakan, membantu dan mengatur posisi duduk dan lain sebagainya. $^{24}$

4. Perkembangan kognitif

Pertumbuhan dan perkembangan dapat diklasifikasikan atas kognitif, psikologis dan fisik.Pertumbuhan dan perkembangan berhubungan dengan perubahan struktur dan fungsi karakteristik manusia. Perubahan tersebut terjadi dalam kemajuan yang mantap dan merupakan proses kematangan. Perubahan ini merupakan hasil interaksi dari potensi bawaan dan lingkungan. ${ }^{25}$

c. Pengembangan kurikulum/silabus

Dalam proses belajar mengajar, kemampuan guru dalam mengembangkan kurikulum/silabus sesuai dengan kebutuhan peserta didik sangat penting, agar pembelajaran dapat berlangsung secara efektif dan menyenangkan. ${ }^{26}$

\section{d. Perancanganpembelajaran}

\footnotetext{
${ }^{22}$ E. Mulyasa, Standar Kompetensi........, 81.

${ }^{23}$ E. Mulyasa, Standar Kompetensi........, 85.

${ }^{24}$ E. Mulyasa, Standar Kompetensi ............, 94.

${ }^{25}$ E. Mulyasa, Standar Kompetensi .............., 95.

${ }^{26}$ E. Mulyasa, Standar Kompetensi ............., 98.
} 
Perancangan pembelajaran merupakan salah satu kompetensi pedagogik yang harus dimiliki guru, yang akan tertuju pada pelaksanaan pembelajaran. Perancangan pembelajaran sedikitnya mencakup tiga kegiatan, yaitu: identifikasi kebutuhan, identifikasi kompetensi, dan penyusunan program pembelajaran. ${ }^{27}$

e. Pelaksanaan pembelajaran yang mendidik dandialogis

Dalam peraturan pemerintah tentang guru dijelaskan bahwa guru harus memiliki kompetensi untuk melaksanakan pembelajaran yang mendidik dan dialogis. Hal ini berarti bahwa pelaksanaan pembelajaran harus berangkat dari proses dialogis antar sesama subjek pembelajaran sehingga melahirkan pemikiran kritis dan komunikatif. Tanpa komunikasi tidak akan ada pendidikan sejati. ${ }^{28}$

f. Pemanfaatan teknologi pembelajaran

Fasilitas pendidikan pada umumnya mencakup sumber belajar, sarana dan prasarana penunjang lainnya, sehingga peningkatan fasilitas pendidikan harus ditekankan pada peningkatan sumber-sumber belajar, baik kualitas maupun kuantitasnya yang sejalan dengan perkembangan teknologi pendidikan dewasa ini. Perkembangan sumber-sumber belajar ini memungkinkan peserta didik belajar tanpa batas, tidak hanya di ruang kelas, tetapi bisa di laboratorium, perpustakaan, di rumah dan di tempattempat lain. Teknologi pembelajaran merupakan sarana pendukung untuk membantu memudahkan pencapaian tujuan pembelajaran dan pembentukan kompetensi, memudahkan penyajian data, informasi, materi pembelajaran, dan variasi budaya. ${ }^{29}$

g. Evaluasi hasil belajar (EHB)

Pengembangan peserta didik untuk mengaktualisasikan berbagai potensi yang dimilikinya. ${ }^{30}$ Istilah prestasi belajar terdiri dari dua kata, yaitu prestasi dan belajar.Menurut Ridwan prestasi adalah hasil yang diperoleh karena aktifitas belajar yang telah dilakukan. ${ }^{31}$ Adapun menurut Abu Muhammad prestasi adalah hasil usaha atau setidaknya selalu dihubungkan dengan aktifitas tertentu. ${ }^{32}$ Sedangkan menurut Sardiman AM yang dimaksud prestasi adalah kemampuan nyata yang merupakan hasil interaksi antar berbagai faktor yang memengaruhi baik dari dalam maupun dari luar individu dalam belajar. ${ }^{33}$

Menurut Hilgrd dan Bower yang dikutip oleh Ngalim Purwanto mengemukakan pengertian belajar sebagai berikut: Belajar berhubungan dengan tingkah laku seseorang terhadapsesuatu situasi tertentu yang disebabkan oleh pengalaman yangberulang-ulang dalam situasi itu, dimana

\footnotetext{
${ }^{27}$ E. Mulyasa, Standar Kompetensi ............., 100.

${ }^{28}$ E. Mulyasa, Standar Kompetensi ............, 103.

${ }^{29}$ E. Mulyasa, Standar Kompetensi ............., 107.

${ }^{30}$ E. Mulyasa, Standar Kompetensi ............., 108.

${ }^{31}$ Ridwan, Belajar, Minat, Motivasi dan Prestasi Belajar(Jakarta: Grafindo Persada, 2008),

${ }^{32}$ Abu Muhammad, (2008), 2.

${ }^{33}$ Sardiman A.M., Interaksi dan Motivasi Belajar Mengajar(Jakarta: CV Rajawali, 2001),
} 3. 46. 
perubahan tingkah laku tidak dapat dijelaskan atau dasar kecenderungan responpembawaan, kematangan, atau keadaan-keadaan sesaat seseorang(misalnya kelelahan, pengaruh obat, dan sebagainya). ${ }^{34}$

Prestasi belajar menurut kamus Besar Bahasa Indonesia adalah penguasaan pengetahuan dan keterampilan yang dikembangkan melalui mata pelajaran, lazimnya ditunjukkan dengan nilai test atau angka nilai yang diberikan oleh guru. ${ }^{35}$ Menurut Nana Sudjana prestasi belajar adalah kemampuan yang dimiliki siswa setelah ia menerima pengalaman belajar. ${ }^{36}$ Sedangkan menurut Syaiful Bahri Djamarah prestasi belajar merupakan hasil dari suatu kegiatan yang telah dikerjakan atau diciptakan secara individu maupun secara kelompok. ${ }^{37}$

Menurut Sumadi Suryabrata prestasi belajar meliputi perubahan psikomotorik, sehingga prestasi belajar adalah kemampuan siswa yang berupa penguasaan pengetahuan, sikap dan keterampilan yang dicapai dalam belajar setelah ia melakukan kegiatan belajar. ${ }^{38}$

Menurut Slameto secara garis beras faktor-faktor yang mempengaruhi prestasi belajar terdiri dari dua golongan, yaitu faktor intern dan faktor ekstern.Faktor intern yaitu faktor yang berasal dari dalam diri siswa, seperti keadaan jasmani, psikologis, intelektual (kecerdasan), minat dan motivasi.Sedangkan faktor ekstern adalah faktor yang berasal dari luar siswa, seperti keluarga, sekolah, masyarakat, sarana dan fasilitas belajar.Kedua faktor ini tidak dapat dipisahkan karena satu dengan yang lainnya adalah saling berkaitan dan dapat memengaruhi hasil belajar siswa. $^{39}$

Metode yang digunakan dalam penelitian ini adalah kuantitatif, uji beda dengan menggunakan pendekatan empiric/lapangan. Adapun langkahlangkah yang penulis tempuh dalam mengumpulkan data yaitu dengan menggunakan beberapa teknik seperti observasi, angket dan dokumentasi. Adapun teknik analisis data yang digunakan dalam penelitian ini ialah teknik analisis data kuantitatif. Sedangkan untuk menganalisa data yang diperoleh peneliti menggunakan skala prosentase, mean, median modus, dan rumus product moment. Populasi dalam penelitian ini yaitu 102 siswa dan sampelnya sebanyak 34 siswa kelas XI-IPS Madrasah Aliyah An-Nur Kota Cirebon.

Adapun hasil dari analisis data yang penulis lakukan diperoleh data sebagai berikut:

${ }^{34}$ Ngalim Purwanto, Psikologi Pendidikan(Jakarta: PT Remaja Rosdakarya, 2003), 84.

${ }^{35}$ Departemen Pendidikan Nasional, Kamus Besar Bahasa Indonesia(Jakarta: Balai Pustaka, 2002), 895 .

22.

${ }^{36}$ Nana Sudjana, Penelitian Hasil Belajar Mengajar (Bandung: Remaja Rosdakarya, 1991),

${ }^{37}$ Syaiful Bahri Djamarah, Prestasi Belajar dan Kompetensi Guru (Jakarta: Rineka Cipta, 1994), 19.

${ }^{38}$ Sumardi Suryabrata, Psikologi Pendidikan(Jakarta: Rajawali Pers, 2005), 175.

${ }^{39}$ Slameto, Belajar dan Faktor-faktor yang Mempengaruhinya(Jakarta: PT Renika Cipta, 2010), 54. 
1. Pengaruh kompetensi pedagogik guru pada pembelajaran Aqidah Akhlak di Madrasah Aliyah (MA) AN-Nur Kota Cirebon

Skor yang digunakan dengan penyusunan kompetensi pedagogik guru pada pembelajaran Aqidah Akhlak kelas XI di Madrasah Aliyah ( MA) An-Nur Kota Cirebon penulis menggunkan indikator: 1) menguasai karakteristik peserta didik dari aspek fisik, moral, spiritual, sosial, kultural, emosional, dan intelektual; 2) menguasai teori belajar dan prinsip-prinsip pembelajaran yang mendidik; 3) mengembangkan kurikulum yang terkait dengan mata pelajaran yang diampu; 4) menyelenggarakan pembelajaran yang mendidik; 5) memanfaatkan teknologi informasi untuk kepentingan pembelajaran; 6) memfasilitasi pengembangan potensi peserta didik untuk mengaktualisasikan berbagai potensi yang dimiliki; 7) berkomunikasi secara efektif, empatik, dan santun dengan peserta didik; 8) menyelenggarakan penilaian dan evaluasi proses dan hasil belajar; 9) memanfaatkan hasil penilaian dan evaluasi untuk kepentingan pembelajarann; 10) melakukan tindakan reflektif untuk peningkatan kualitas pembelajaran. Penulis menyebarkan angket yang berisi 25 pernyataan positif untuk diisi oleh 34 siswa dengan pilihan jawaban selalu, sering, kadang-kadang, dan tidak pernah. Data hasil perhitungan tersebut dapat peneliti simpulkan bahwa rata-rata kompetensi pedagogik guru pada pembelajaran Aqidah Akhlak di Madrasah Aliyah (MA) An-Nur Kota Cirebon termasuk dalam kategori baik dengan 83,58 \% karena pada interval 75-100 \%.

2. Prestasi Belajar Siswa pada pembelajaran Aqidah Akhlak siswa kelas XI Madrasah Aliyah (MA) An-Nur Kota Cirebon

Berdasarkan perhitungan nilai rapot siswa kelas XI-IPS dari 34 siswa diperoleh rata-rata (mean) 82,4 berada dalam interval 75-85 termasuk dalam kategori baik. Sedangkan median sebesar 81,5 berada dalam interval 75-85 termasuk dalam kategori baik, dan modus sebesar 80 berada dalam interval 7585 termasuk dalam kategori baik.

3. Pengaruh Kompetensi Pedagogik Guru terhadap Prestasi Belajar Siswa pada Pembelajaran Aqidah Akhlak

Perhitungan Korelasi Product Moment antara Kompetensi Pedagogik Guru (Variabel X) dengan Prestasi Belajar Siswa (Variabel Y) Madrasah Aliyah (MA) An-Nur Kota Cirebon

\begin{tabular}{|c|c|c|c|c|c|}
\hline No & $\mathrm{x}$ & $\mathrm{y}$ & $\mathrm{x} 2$ & $\mathrm{y} 2$ & $\mathrm{xy}$ \\
\hline 1 & 80 & 80 & 6400 & 6400 & 6400 \\
\hline 2 & 74 & 76 & 5476 & 5776 & 5624 \\
\hline 3 & 80 & 77 & 6400 & 5929 & 6160 \\
\hline 4 & 78 & 84 & 6084 & 7056 & 6552 \\
\hline
\end{tabular}




\begin{tabular}{|c|c|c|c|c|c|}
\hline 5 & 57 & 84 & 3249 & 7056 & 4788 \\
\hline 6 & 76 & 86 & 5776 & 7396 & 6536 \\
\hline 7 & 79 & 81 & 6241 & 6561 & 6399 \\
\hline 8 & 82 & 89 & 6724 & 7921 & 7298 \\
\hline 9 & 80 & 80 & 6400 & 6400 & 6400 \\
\hline 10 & 74 & 79 & 5476 & 6241 & 5846 \\
\hline 11 & 75 & 82 & 5625 & 6724 & 6150 \\
\hline 12 & 79 & 79 & 6241 & 6241 & 6241 \\
\hline 13 & 80 & 80 & 6400 & 6400 & 6400 \\
\hline 14 & 87 & 80 & 7569 & 6400 & 6960 \\
\hline 15 & 80 & 81 & 6400 & 6561 & 6480 \\
\hline 16 & 80 & 75 & 6400 & 5625 & 6000 \\
\hline 17 & 79 & 85 & 6241 & 7225 & 6715 \\
\hline 18 & 87 & 78 & 7569 & 6084 & 6786 \\
\hline 19 & 78 & 85 & 6084 & 7225 & 6630 \\
\hline 20 & 80 & 80 & 6400 & 6400 & 6400 \\
\hline 21 & 85 & 80 & 7225 & 6400 & 6800 \\
\hline 22 & 84 & 80 & 7056 & 6400 & 6720 \\
\hline 23 & 80 & 82 & 6400 & 6724 & 6560 \\
\hline 24 & 87 & 84 & 7569 & 7056 & 7308 \\
\hline 25 & 79 & 88 & 6241 & 7744 & 6952 \\
\hline 26 & 82 & 80 & 6724 & 6400 & 6560 \\
\hline 27 & 84 & 86 & 7056 & 7396 & 7224 \\
\hline 28 & 85 & 80 & 7225 & 6400 & 6800 \\
\hline 29 & 80 & 80 & 6400 & 6400 & 6400 \\
\hline 30 & 90 & 85 & 8100 & 7225 & 7650 \\
\hline 31 & 80 & 90 & 6400 & 8100 & 7200 \\
\hline 32 & 80 & 89 & 6400 & 7921 & 7120 \\
\hline 33 & 86 & 87 & 7396 & 7569 & 7482 \\
\hline 34 & 80 & 85 & 6400 & 7225 & 6800 \\
\hline
\end{tabular}




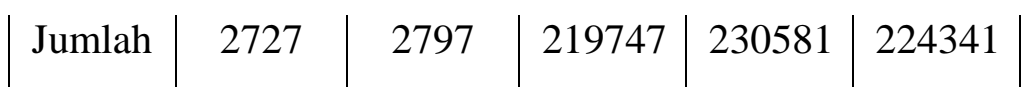

Langkah perhitungannya adalah sebagai berikut:

1. Menjumlahkan skor $\mathrm{x}$, diperoleh $\sum X=2727$

2. Menjumlahkan skor $y$, diperoleh $\sum Y=2797$

3. Menjumlahkan skor $X^{2}$, diperoleh $\sum X^{2}=219747$

4. Menjumlahkan skor $Y^{2}$, diperoleh $\sum Y^{2}=230581$

5. Menjumlahkan skor $X Y$, diperoleh $\sum X Y=224341$

Data yang telah didapat dalam bentuk angket hasil tes, selanjutnya diolah menggunakan perhitungan korelasi Spearmen atau yang sering disebut dengan korelasi Product Moment, hal ini digunakan untuk mengetahui apakah terdapat korelasi antara variabel $\mathrm{x}$ dan variabel $\mathrm{y}$. Perhitungan rumusnya sebagai berikut :

$$
r_{x y}=\frac{\mathrm{N} \Sigma \mathrm{xy}-(\Sigma \mathrm{x})(\Sigma \mathrm{y})}{\sqrt{\left\{\mathrm{N} \Sigma \mathrm{x}^{2}-(\Sigma \mathrm{x})^{2}\right\}\left\{\mathrm{N} \Sigma \mathrm{y}^{2}-(\Sigma \mathrm{y})^{2}\right\}}}
$$

Keterangan:

$r_{x y}:$ koefisien korelasi antara $\mathrm{x}$ dan $\mathrm{y}$

$\mathrm{X} \quad$ : jumlah skor item variabel $\mathrm{x}$

$\mathrm{Y} \quad$ : jumlah skor item variabel $\mathrm{y}$

$\mathrm{X}^{2} \quad$ : jumlah kuadrat skor item variabel $\mathrm{x}$

$\mathrm{Y}^{2} \quad$ : jumlah kuadrat skor item variabel $\mathrm{y}$

$\mathrm{XY}$ : jumlah perkalian skor item variabel $\mathrm{x}$ dan $\mathrm{y}$

$\mathrm{N} \quad$ : jumlah responden

$$
\begin{aligned}
& r_{x y}=\frac{N \sum x y-\left(\sum x\right)\left(\sum y\right)}{\sqrt{\left.\left\{N \sum x^{2}-\left(\sum x\right)^{2}\right\} N \sum y^{2}-\left(\sum y\right)^{2}\right\}}} \\
& =\frac{34.224341-(2727)(2797)}{\sqrt{\left\{34 \sum 219747-(2727)^{2}\right)\left\{34 \sum 230581-(2797)^{2}\right\}}} \\
& =\frac{7627594-7627419}{\sqrt{\sqrt{\{7471398-7436529\}\{}\{7839754-7823209\}}} \\
& =\frac{175}{\sqrt{(34869)(16545)}}
\end{aligned}
$$




$$
\begin{aligned}
& =\frac{175}{\sqrt{576907605}} \\
& =\frac{175}{24018} \\
& =0,729
\end{aligned}
$$

Nilai korelasi dari hasil perhitungan diatas, selanjutnya dihitung nilai koefisien determinasinya, untuk mengetahui apakah ada pengaruh antara kompetensi pedagogik guru (variabel $\mathrm{x}$ ) dengan prestasi belajar siswa pada pembelajaran Aqidah Akhlak (variabel y), rumusnya sebagai berikut :

$$
\begin{aligned}
\mathrm{KD} & =\mathrm{r}^{2} \times 100 \% \\
& =0,729^{2} \times 100 \% \\
& =0,531441 \times 100 \% \\
& =53,14 \%
\end{aligned}
$$

Hasil dari koefisien determinasi di atas, menunjukan bahwa pengaruh kompetensi pedagogik guru terhadap prestasi belajar siswa Madrasah Aliyah (MA) An-Nur Kota Cirebon studi pada pembelajaran Aqidah Akhlak di kelas XI sebesar $53,14 \%$. Dan $46,86 \%$ berhubungan dengan faktor lain, misalnya faktor lingkungan, keluarga, IQ dan sebagainya yang berpengaruh terhadap prestasi belajar siswa.

\section{Kesimpulan}

1. Berdasarkan rekapitulasi rata-rata hasil angket variable $X$ mengenai kompetensi pedagogi guru pada pembelajaran Aqidah Akhlak di Madrasah Aliyah (MA) An-Nur Kota Cirebon termasuk dalam kategori dengan nilai $83,58 \%$ karena berada pada interval $75 \%$ - $100 \%$ termasuk dalam kategori baik.

2. Tingkat prestasi belajar siswa pada pembelajaran Aqidah Akhlak di Madrasah Aliyah (MA) An-Nur Kota Cirebon siswa diperoleh rata-rata (mean) 82,4 berada dalam interval 75-85, termasuk dalam kategori baik. Sedangkan median sebesar 81,5 berada dalam interval 75-85, termasuk dalam kategoribaik. dan modus sebesar 80 berada dalam interval 75-85 termasuk dalam kategori baik.

3. Pengaruh kompetensi pedagogik guru terhadap prestasi belajar siswa Madrasah Aliyah (MA) An-Nur Kota Cirebon (Studi pada pembelajaran Aqidah Akhlak dikelas XI) dimana dilihat dari " $r$ " product moment dihasilkan nilai $r$ sebesar 0,729 kemudian $r$ hitung di atas konsultasikan ke $r$ tabel pada sample sebesar 34 diperoleh $r$ tabel sebesar 0,349. Dengan begitu dapat dikatakan bahwa $r$ hitung berada di atas $r$ tabel, maka uji hipotesis menjawab $\mathrm{H}_{\mathrm{o}}$ ditolak dan $\mathrm{H}_{\mathrm{a}}$ diterima. 


\section{DAFTAR PUSTAKA}

Departemen Pendidikan Nasional.2002. Kamus Besar Bahasa Indonesia. Jakarta: Balai Pustaka.

Djamarah, Syaiful Bahri. 1994. Prestasi Belajar dan Kompetensi Guru.Jakarta: Rineka Cipta.

Irwantoro, Nur dan Yusuf Suryana. 2016. Kompetensi Pedagogik. Surabaya: Genta Group Production.

Jamil, Supratiningrum. 2014. Guru Profesional Pedoman Kinerja, Kualifikasi, dan Kompetensi Guru. Jogjakarta: Ar Ruzz Media.

Kementrian Agama. 2009. Al-Qur'an dan Terjemahan. Jakarta: PT Sinergi Pustaka Indonesia.

Kusnandar. 2007. Guru Profesional (Implementasi KTSP dan Sukses dalam Sertifikasi Guru). Jakarta: Rajawali Perss.

Mulyasa, E. 2011.Standar Kompetensi dan Sertifikasi Guru.Bandung: PT Remaja Rosdakarya.

Musfah, Jejen. 2012. Peningkatan Kompetensi Guru (Melalui Pelatihan dan Sumber Belajar Teori dan Praktek). Jakarta: Kencana Prenada Media Group.

Purwanto, Ngalim. 2003. Psikologi Pendidikan. Jakarta: PT Remaja Rosdakarya.

Ridwan. 2008. Belajar, Minat, Motivasi dan Prestasi Belajar. Jakarta: Grafindo Persada.

Sardiman A.M. 2001. Interaksi dan Motivasi Belajar Mengajar.Jakarta: CV Rajawali.

Slameto. 2010. Belajar dan Faktor-faktor yang Mempengaruhinya. Jakarta: PT Rineka Cipta.

Sudjana, Nana. 1991. Penelitian Hasil Belajar Mengajar. Bandung : Remaja Rosdakarya.

Suryabrata, Sumadi. 2005. Psikologi Pendidikan. Jakarta: Rajawali Pers.

Trianto. 2011. Pengantar penelitian Pendidikan bagi pengembangan profesi pendidikan dan tenaga kependidikan. Jakarta: Bumi Aksara.

Usman, Uzer Muhammad. 2006. Menjadi Guru Profesional. Bandung: Remaja Rosdakarya.

Undang-Undang RI tentang Guru dan Dosen No 14 Tahun 2005. Jakarta: Sinar Grafika. 